\title{
The eclipse and rehabilitation of JJR Macleod, Scotland's insulin laureate
}

\author{
M Bliss \\ University Professor Emeritus, University of Toronto, Ontario, Canada
}

\begin{abstract}
This paper is adapted from the Douglas Guthrie History of Medicine Lecture held at the Royal College of
\end{abstract} Physicians of Edinburgh on 6 November, 2013

\begin{abstract}
John JR Macleod (1876-1935,) an Aberdonian Scot who had emigrated to North America, shared the 1923 Nobel Prize with Frederick Banting for their discovery of insulin at the University of Toronto in 1921-22. Macleod finished his career as Regius Professor of Physiology at the University of Aberdeen from 1928 to 1935. Macleod's posthumous reputation was deeply tarnished by the campaigns against him carried out by his fellow laureate, Banting, and by Banting's student assistant during the insulin research, Charles Best. Banting's denigration of Macleod was based on their almost total personality conflict; Best's was based on a hunger for personal recognition. New research indicates how scarred both men were in their obsessions. The rehabilitation of Macleod's reputation, begun in 1982 with my book, The Discovery of Insulin, has continued in both scholarly and popular circles. By 2012, the ninetieth anniversary of the discovery of insulin, it had become complete both at the University of Toronto and in Canada.
\end{abstract}

\author{
Correspondence to $M$ Bliss \\ $3 / 4$ Bessborough Drive \\ Toronto, Ontario \\ Canada, M4G 3 LI
}

e-mail m.bliss@sympatico.ca

KEYWORDS Insulin, diabetes, discovery, Macleod, Banting, Best

DECLARATIONS OF INTERESTS No conflicts of interest declared.

\section{INTRODUCTION}

On 8 November 1920, John JR Macleod (Figure I), the Scottish-born and educated Professor of Physiology at the University of Toronto, met for the first time a young Canadian physician, Frederick Banting. Banting hoped Macleod would help him try out a research idea aimed at isolating the internal secretion of the pancreas. Macleod agreed to take Banting into his department, give him research animals and a student assistant, Charles Best (Figure 2), and advise on his plan of work. The research began on 17 May 1921; as it developed that summer and autumn, Macleod actively supervised a collaborative effort that eventually utilised the full resources of his laboratory.

In January 1922 extracts of animal pancreas, prepared by Banting, Best, and a biochemist, James B Collip, (Figure 3) following suggestions made by Macleod, proved spectacularly effective in relieving the symptoms of humans with type I diabetes. On 3 May 1922, Macleod read a paper to the American Association of Physicians, co-authored by Banting, CH Best, JB Collip, WR Campbell, AA Fletcher, and EC Noble, 'The Effect Produced on Diabetes by Extracts of Pancreas.' The audience, which included America's leading diabetologists, gave the Toronto group a standing

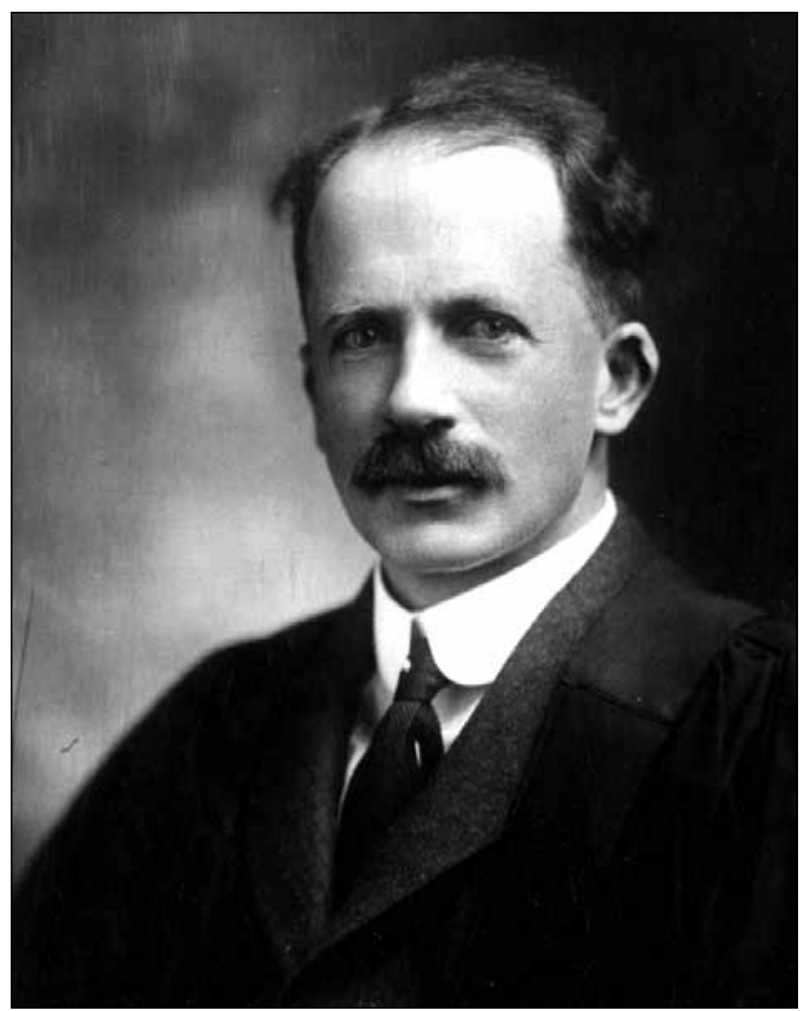

FIGURE I JJR Macleod (1876-1935). University of Toronto. 


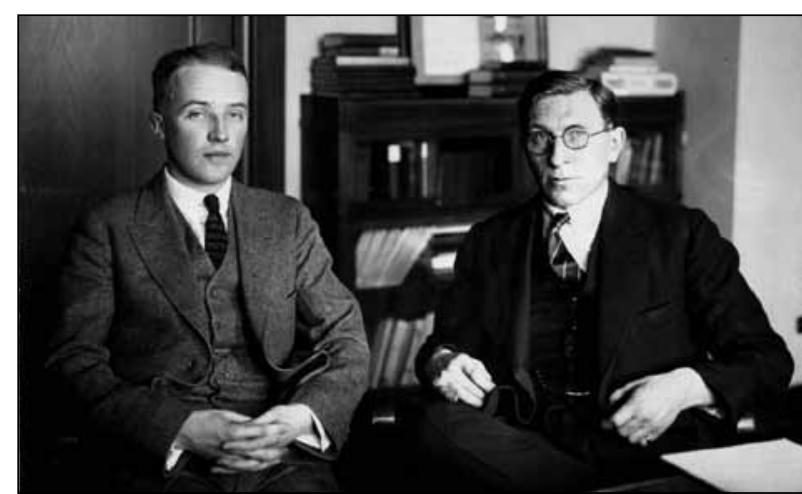

FIGURE $2 \mathrm{CH}$ Best and FG Banting c. 1924. University of Toronto.

ovation for the work they had done in isolating the pancreatic hormone that controlled metabolism, which they named 'insulin'. In October 1923 it was announced in Stockholm that Frederick Banting and John JR Macleod would share the 1923 Nobel Prize in Physiology or Medicine for the discovery of insulin.

Macleod directed foundational research into the physiology of insulin at the University of Toronto until 1928 when he returned to his home city of Aberdeen to become Regius Professor of Physiology at his Alma Mater. Showered with honours throughout the scientific world - his insulin work having capped an already hugely productive career in science - the Nobel laureate taught and did research in Aberedeen until his death in 1935 at the comparatively young age of 58 .

The basic biographical literature on Macleod includes the published version of a paper I delivered at The Physiological Society's 1988 Aberdeen meeting ${ }^{2}$ and a 1993 monograph by Dr Michael J Williams of Aberdeen, JJR Macleod: The Co-discover of Insulin. ${ }^{3}$ My 1982 book, The Discovery of Insulin, ${ }^{4}$ continues to be referred to as the standard account of both the discovery and the issue of the apportionment of credit among the members of the Toronto team. In it I conclude that JJR Macleod was a worthy Nobel laureate.

This brief summary masks the story of a remarkable reputational rollercoaster ride. It involved the deliberate blackening of JJR Macleod's reputation by his co-workers, and then Macleod's rehabilitation in our time. The rehabilitation was finally completed in Canada and at the University of Toronto only in 2012, the ninetieth anniversary of the discovery of insulin. Understanding these developments may also ensure that Macleod's achievements as a research scientist, a Nobel laureate, a co-discoverer of insulin - will now also be fully appreciated in his native land.

\section{BANTING'S CAMPAIGN}

In The Discovery of Insulin and its sequel, Banting: $A$ Biography, ${ }^{5}$ I was able to describe the insulin research from original notebooks and publications, private correspondence, and extensive interviews of dozens of eyewitnesses to history (almost all of whom have since died). Underlying the narrative of an epoch-making event in medical research, one of the first and most dramatic conquests of a deadly disease, is also the story of intense, even violent personality conflicts among the discoverers of insulin.

The most basic clash was between Banting and Macleod. Banting was an impetuous, rough-hewn physician whose enthusiasm for his research was as boundless as his inexperience and ignorance of the science involved in what he was trying to do. Macleod was an expert, cautious scientist, well aware of the pits into which young researchers who over-claimed could disappear. From their first meeting it was clear that Banting and Macleod were temperamentally incompatible.At the end of the summer of 1921 they quarreled bitterly about research facilities and priorities, and then as the results became more exciting in the winter of 1921, Macleod found to his complete surprise that Banting was accusing him of stealing credit for work that was not properly his.

Banting believed that his experiments on dogs in the summer of 1921 had been sufficient to prove the soundness of his idea, that they had amounted to the discovery of insulin, and that Macleod's input had been primarily in the development of the discovery during the winter of 1921-22. Banting's most spectacular outburst came in a confrontation with the fourth member of the group, the biochemist Collip, on the night in January 1922 when Collip told Banting that purified extract worked on a human patient and then declined to tell him details of the purification process. They came to blows in the laboratory and had to be separated by Banting's assistant, Best.

During these months Banting, who developed for a time a serious drinking problem, was convinced that Macleod and Collip were appropriating his rightful glory. With the help of Best and other friends, and various neutral interveners, Banting managed to stabilise himself and carry on clinical work with insulin in a coldly proper modus vivendi with Macleod. The documents show that he never appreciated Macleod's vital contributions throughout the research. These contributions included giving Banting and Best crucial advice on how to prepare the pancreatic extracts that proved effective, guiding their work to prevent the confused, novice researchers from going off the rails, and orchestrating successful clinical trials and elaborative physiological studies. Banting never understood the limitations of his idea, his experiments, his judgment. 


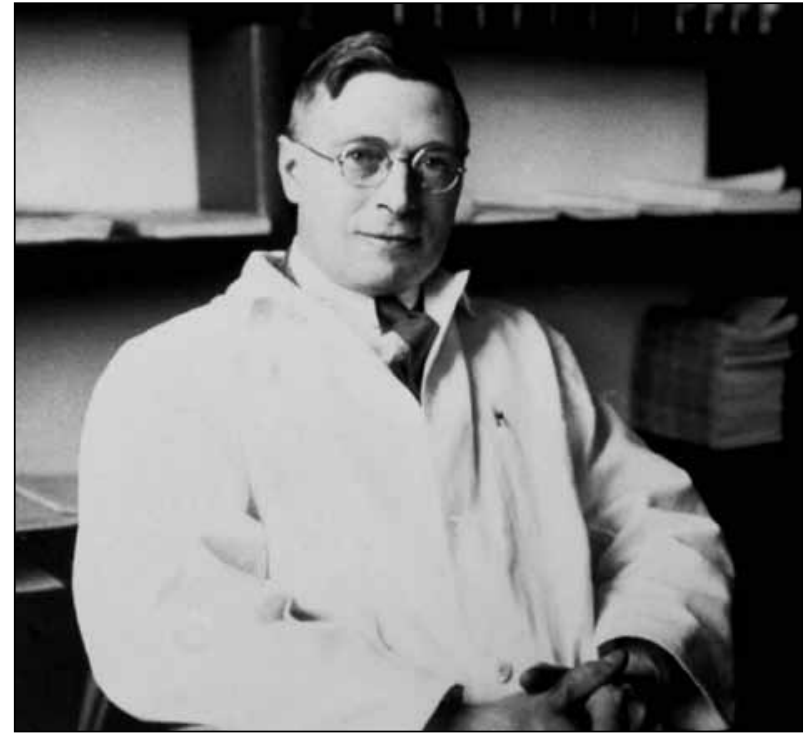

FIGURE 3 JB Collip in his office at McGill University c. 1930. University of Toronto.

Macleod continued to guide the work, which moved with breathtaking speed to the commercialisation of insulin as a life-sustaining therapy for thousands of people with diabetes. He was personally highly discrete, and did not readily volunteer details of his difficulties with Banting, but did refer in letters to 'this fresh outbreak of Banting's' ...'an extremely uncomfortable position here' ...'unbelievable trouble.'

Banting had shared his anger at Macleod with various of his friends, particularly a hero-worshipping former teacher of his, a DrWilliam Ross. In 1923 Ross organised a campaign in Canada to have Banting recognised as the discoverer of insulin. ${ }^{7}$ It was largely successful - Banting was given a special annuity by the government of Canada, and a special chair at the University of Toronto - but did not work at the international level. The Nobel Committee of the Karolinska Institute, weighing nominations of Banting and Macleod singly and jointly, investigated the Toronto research carefully and deliberately and with some knowledge of the controversy, and concluded that Banting could not have reached insulin without the contributions of Macleod. Hence the joint 1923 award.

Banting was initially enraged that he would have to share the Prize with Macleod and in a fit of temper announced that he would share his prize money with Best. Macleod then announced that he was sharing his prize money with Collip, whose purification of the extract was the single most important step in bringing the research to convincing success.

Aside from the odd public distribution of the Nobel cash, the Toronto community and the researchers themselves managed to cover up most of the details of the Banting-Macleod conflict, and for the next five years in Toronto the city was big enough for both Nobel laureates - barely. Stories circulated about them not speaking, their wives not socialising or speaking, and Macleod telling friends that by 1928 he felt he had either leave Toronto or take legal action against Banting. When Macleod was on the club car preparing to leave Toronto for the last time, he told an acquaintance that he was shuffling his feet to wipe away the dirt of the city.

After Macleod left the University of Toronto, the two Canadians he had guided to insulin were left in positions of power and prominence. Banting had his own chair and separate department of medical research. Charles Best, who had finished his training as a physiologist with Sir Henry Dale in London, replaced Macleod in Physiology. To its credit, the University of Toronto held a glittering farewell dinner with Macleod. To his discredit, Banting declined to attend, suggesting that an empty chair represent him. $^{8}$ In 1930 the university named new medical laboratories the Banting Institute. It named nothing after Macleod.

Banting never changed his view of Macleod. It is reflected in his still unpublished (because it is rambling and unreliable) 1940 manuscript account of the discovery of insulin, which includes a passage about Macleod remarkable in its verbal violence against 'the most selfish man I have ever known ...grasping, selfish, deceptive, self-seeking and empty of truth ...unscrupulous ...a coward and a skulking weakling."

We now have new first-hand accounts of Banting's personality, during and after the insulin research. The recent donation to the Thomas Fisher Library of the University of Toronto of the papers of DrWilliam Ross, mentioned above, who knew Banting intimately and proposed to be his first biographer, sheds intense, confirming light on the recent medical graduate and war veteran who is still the youngest Nobel laureate. In memoranda, draft chapters, and interview notes, Ross reinforces the view of Banting as a lonely, poorlyeducated, and often paranoid newcomer to serious research. In good times Banting joked about being the worst educated medical graduate the University of Toronto had ever produced. In bad times, during the insulin research, he threatened to commit suicide. Notes in the Ross Papers reinforce the suspicion that Banting may physically have attacked his collaborators on more than the one occasion we can document. There were probably occasions on which Banting inflicted wild verbal and possibly physical abuse on Macleod. ${ }^{10}$

\section{BEST'S CAMPAIGN}

Banting did change his attitude to Charles Best, the 22 -year-old science student who in 1921 won a coin toss with another student to see who would help Banting first. Best had been Banting's student assistant, a 
definite underling. The two men bonded emotionally during their research adventure in the summer of 1921, and Best became instrumental in helping pull Banting out of a near-breakdown in the winter of 1922. But Banting never thought of their relationship as a partnership of scientific equals.

Best, he seemed to think, was his faithful batman, whose contributions should be elevated and praised on occasion - especially in contrast to those of the evil Macleod - but who did not really have a claim on the true hardware of scientific glory, such as the explicit Nobel Prize. Banting, who believed that his original idea was the key to the discovery, was most content to be hailed as the sole discoverer of insulin, helped occasionally by Best.

As time passed in Toronto, Banting decided that Best, whose importunings at not being given more credit during the insulin years had often grated on him, had an impossibly swollen ego. Banting came to dislike Best intensely. The Ross Papers further confirm judgments offered in Banting: A Biography that Banting and his friends felt Best did not deserve anything like equal recognition with Banting as a discoverer of insulin. In the last interview he ever gave on the subject, according to Ross, Banting credited Collip's contributions to the research as being far more important than those of Best."

The world did not know this, and would not for many years. After Banting's death, the University of Toronto, whose officers also did not know the inner history of the former partners' rivalry, gave Banting's chair to the person who seemed to be his logical heir, Best. Macleod and Banting were dead. Collip, who never taught at Toronto, spent his career as a hard-working (and very productive) scientist at the University of Alberta, McGill University, and the University of Western Ontario. ${ }^{12} \mathrm{His}$ attitude towards insulin controversies was that the truth might come out after they were all dead. The field was thus left open for Charles Best to talk about the discovery of insulin, to be recognised for his role in the discovery of insulin, to write the history of the great event, and to continue the denigration of JJR Macleod.

During my initial research, I came across a great deal of manuscript evidence of Charles Best's emergence from Fred Banting's shadow and his re-invention of himself as an equal partner in the discovery of insulin. It was a process mentioned obliquely in my first two books, but in 1993, after the death of Best's widow, I pulled all the evidence together in a paper 'Rewriting Medical History: Charles Best and the Banting and Best Myth', published in The Journal of the History of Medicine and Allied Sciences. The article documents how, beginning about 1946 and for the rest of his life, Charles Best attempted to rewrite the history of the discovery of insulin in his favour, with considerable success. ${ }^{13}$
In innumerable talks and articles about the events of 192I-22, Best systematically elevated his role in the research, reducing the contributions of Banting and Macleod, and ignoring Collip practically entirely. He portrayed JJR Macleod as a kind of caricature, an authoritarian 'Herr Geheimrat' professor, who had no hesitation in taking credit for ideas and suggestions Best could not remember him making. Best encouraged his audiences, and especially his friends, in the thought that Charles Best was the innocent victim of a grave injustice in the award of the 1923 Nobel Prize. The Nobel Committee had made a mistake. The Prize should have gone to Banting and Best.

Best had many friends. He was a charming, usually sociable man who cultivated networks of influential contacts, not unlike his British mentor, Henry Hallett Dale, who himself was one of Best's most important connections and promoters. For the first 20 years or so after the discovery of insulin Best, like Banting and Collip, had gone on to work in other areas of science, enjoying moderate, but not sensational success. In the 1940s he returned to the world of diabetes, which was beginning to frame itself with the creation of an institutional framework to support what was now realised would be a diabetic lifestyle, even a culture built around diabetes. ${ }^{14}$ In the late 1940s Best was one of the founders of the Canadian Diabetes Association. Years earlier as a student in London he had become a close friend of other association founders, especially Dr Robin D Lawrence, who had insulin-dependent diabetes and with HG Wells in 1933-34 created the British Diabetic Association. Best's American friends, dating from insulin days and contacts with Elliott Joslin and the diabetes workers at Eli Lilly and Company, included the founders of the American Diabetes Association in 1940-4I. In 1952 Best, Lawrence, and various of his other friends were among founders of the International Diabetes Federation. ${ }^{15,16}$

It was natural for these associations and their members to want to honour - to celebrate - the coming of insulin. When they turned to living discoverers to honour, there in Toronto was the head of the Banting and Best Department of Medical Research and the Department of Physiology, Charles Best. Best had virtually total licence to describe to an uncritical indeed an adoring - diabetes world how things had really happened back in the early 1920s when he had formed his partnership with Fred Banting and they had carried on their research without significant help, indeed with neglect, hindrance, or even worse from JJR Macleod.

The medals and awards and special lectureships and chairs and institutes that proliferated in the diabetes community from the 1940s through the 1960s were usually named after Banting, or Best, or Banting and Best. 
Best of all, as it were, was the opening of the Best Institute at the University of Toronto, next door to the Banting Institute, at a glittering medical celebration in 1953. The keynote speaker was Sir Henry Dale; his address, of course, was a fulsome tribute to the work and vision of Charles Best.

Banting had always been a favourite of clinicians in the diabetes world because in the early days of insulin he had seemed to be the clinical leader, the bedside man. Macleod had been a remote and distant physiologist, a laboratory man who soon disappeared back to a remote city in Scotland and then died. By the 1950s Best had succeeded in persuading almost everyone that he, Best, had been the key scientist on the insulin team. 'Nobody now thinks of Macleod as having played any serious part in the discovery of Insulin,' Dale wrote to Best in 1961. 'All the world now thinks only of Banting and Best as the essential discoverers, and, since Fred Banting's tragic death, the interest of everybody concerned to expound or commemorate the discovery of Insulin has naturally, and properly, become centred on yourself. ${ }^{\prime 7}$

How widely credited was the Banting and Best version? It is not really surprising that in Canada a kind of scientific nationalism would favour stories about the two brilliant and intrepid young Canadians. But it also happened in the UK. The 2012 biography of RD Lawrence, for example, makes no mention of Lawrence ever crediting Macleod with significance in the insulin story, while containing innumerable references to the deep friendship between Lawrence and Best, their genial socialising, and work together in diabetes associations. ${ }^{16}$ Lawrence in fact was, like Macleod, a former pupil of the Aberdeen Grammar School and the medical school of the University of Aberdeen. As probably the most influential figure in British diabetes in the 40 years after the discovery of insulin, Lawrence not only ignored the countryman responsible for saving his life, but privately told interviewers that he thought Macleod was a 'rascal. ${ }^{18}$

A further twist to the UK insulin story involved the role of Best's former supervisor and closest British friend, his patron, Sir Henry Dale, 1936 Nobel Laureate, former secretary and president of the Royal Society of London, former holder of many high positions in British science, showered with honours, and one of the most prominent and powerful scientists in the kingdom. It was Dale who came out to Canada in 1922 to learn about insulin and then engineer its development in the UK by the Medical Research Council (MRC). Dale later played an important role in the international standardisation of insulin.

Dale never seems to have liked Macleod. There are complex reasons for this, which include a clear (and mistaken) belief that Macleod had mishandled the development of insulin in Toronto. There may have been past rivalries between the two men. Dale may also have been envious of the fame Macleod got for insulin and his Nobel Prize. Dale's award, for acetylcholine, came a long 13 years later. Most speculatively but perhaps most interestingly, at least for Scots readers, there was the possibility that was put to me verbally 32 years ago when I first visited Scotland to do my Macleod research. The former students and colleagues of Macleod whom I interviewed - JM Peterson, lan Anderson, and especially Dr Robert Garry - tended to the view that Macleod had been neglected by Dale and the British medical establishment because Scottish scientists were habitually neglected by Dale and the British medical establishment. Science in the UK had been run from London and Cambridge, and if you were not a member of those august circles you were an outsider, even if you had won a Nobel Prize. ${ }^{9}$ If Canadian nationalism lurks in explaining the triumph of the Banting and Best myth in North America, possibly an element of English chauvinism helped foster the eclipse of JJR Macleod in the UK. In 1993 I suggested that a critical biography of $\mathrm{HH}$ Dale is badly needed..$^{20}$

In 2003 an uncritical, but highly revealing major biography of Charles Best and his wife, Margaret, written by their son, Henry, was published in Canada. It more than reinforces the portrait of Best that I had sketched earlier. Charles Best was emotionally, psychologically needy at the best of times, and at certain periods in his life his needs immobilised him in a form of severe depression that had inflicted previous generations of his family. ${ }^{21}$ Best's pathological appetite for assurance, in the context of the endless opportunities given him by his position, had driven him in a sad quest to rewrite history in his favour. His doting wife and her doting sister, who had been Best's secretary, and some of their sycophantic friends, encouraged him in this endeavour. Unfortunately we still do not have the badly needed biography of the most powerful of these friends, Best's patron, Dale.

\section{MACLEOD ECLIPSED?}

In the 1970s, 50 years after the discovery of insulin, JJR Macleod's role in the achievement was almost universally ignored, or worse. Even at the University of Aberdeen, where his fame had been considerable, his medals were effectively in storage and the title for the chair in biochemistry that had been named after him was almost never used..$^{22}$ Among his own descendants, as Mr lain Macintyre related to me in an email about this paper, memories of JJRM were 'tinged with sadness resulting from the continuing suggestion that his Nobel Prize was undeserved. ${ }^{23}$

In Canada, the home of insulin, there was virtually no memory of Macleod. All popular histories of the great discovery either ignored or denigrated him. It had been 
widely agreed that scholarly histories of the discovery of insulin could not be written until the last of the discoverers - Best - had died. When I proposed to write a scholarly history in 1979, not long after Best's death, I was immediately approached by a prominent Toronto diabetes doctor, who had worked with Banting and befriended Best's widow. He told me that anyone in Toronto who challenged the 'beautiful fairy tale' of Banting and Best would be endangering his position in the faculty of medicine. ${ }^{24}$ Fortunately at that time my appointment was in the faculty of arts and science.

On the other hand, throughout the years when Banting and then Best were gathering all the insulin glory they could, there had been undercurrents of resistance. While JB Collip, who lived until 1965, had never publicly commented on the insulin story, he too had many friends in Canadian academic and global endocrinological circles. His occasional discomfort at Best's distortions sometimes surfaced in high circles. Dale, for example, had to backtrack from some of the distortions in his address at the opening of the Best Institute. Eventually even Dale urged Best to tone down his attacks on his collaborators as something of an embarrassment. ${ }^{12}$

In the scientific community there had been a few independent investigators who in studying the insulin literature had realised how flawed Banting and Best's research had been and how dependent they had been on their seniors. Highly critical appraisals of their research had appeared in print in 1922 and 1954. ${ }^{25,26}$ There was also an important document that was not in print, but that circulated for some 20 years in the UK and Canada. It was JJR Macleod's own account of the discovery of insulin, written in September 1922 at the request of a Governor of the University of Toronto, and containing a full and powerful explanation and justification of the role Macleod had played in the insulin research. The document had survived in Macleod's papers in Scotland, and had found its way to certain people in Canada, mostly friends of Collip's. When Charles Best learned of their interest in publishing Macleod's story he persuaded the president of the University of Toronto, to pressure (quite improperly) a medical historian, Lloyd Stevenson, to suppress it.

But Macleod's account continued to circulate in samizdat form, and, without my knowing it, it had a transformative influence on my life. When Collip died in 1965 the chair of physiology at McGill University, Dr Hank Mclntosh, saw the document as part of his attempt to write a Collip obituary. He gossiped about it to various of his colleagues at McGill including my older brother, a physiologist there. My brother then wrote to me suggesting that we collaborate to tell the true story of the discovery of insulin after the last discoverer died. ${ }^{24}$
Thus I became interested in the subject, knowing that mysterious new documentation existed. Immediately after Best's 1978 death, while I was beginning to launch my project (my brother having died some years earlier), Lloyd Stevenson published Macleod's account in the Bulletin of the History of Medicine. ${ }^{27}$ It proved to be the tip of an iceberg of new source material I was then able to uncover, both archivally and through interviews. People came to me, like the distinguished endocrine psychiatrist RH Cleghorn, who had worked with all of the discoverers, including Macleod in Aberdeen, knew them all well, and delighted in the possibility that an objective history would now be written. After our first luncheon Dr Cleghorn told me he would send me one of his papers that would help me understand Best. The document that arrived in the mail a few days later was entitled 'Megalomania'. ${ }^{24}$

\section{MACLEOD REHABILITATED}

In The Discovery of Insulin I concluded that insulin emerged at the University of Toronto as the result of a collaborative process, initiated by Banting, directed by Macleod, drawing on the great resources of the University of Toronto. This account was immediately accepted in the diabetes and scientific world (except for an odd controversy that continued to simmer about one predecessor, the viciously fascist and anti-semitic Romanian scientist, Nicolae Paulesco), ${ }^{28,29}$ and has not been challenged in the more than 30 years that the book has been in print.

The book's publication helped spark a broader campaign to rehabilitate Macleod. It was a personal pleasure to return to Scotland in 1988, to the Aberdeen meeting of The Physiological Society, and give the special lecture on Macleod that was then published in The Quarterly Journal of Experimental Physiology. Dr Michael Williams of Aberdeen by then was beginning work on the full biography of Macleod that would be published in 1993, also the year of publication of my article detailing Charles Best's attempts to rewrite history. As mentioned, the only new sources that have come to light in the current century - with the acquisition of the WR Ross Papers and through the Charles Best biography reinforce our understanding of how and why Banting and Best carried out their campaigns to denigrate Macleod.

Historical reputations rise and fall not only in scholarly circles, but also with the lay public. This is particularly true of such easily understandable and influential discoveries as insulin. From high school science students through the millions of people involved in insulin and diabetes, through organisations, museums and governments, through ordinary Canadians and Scots who happen to take an interest in the achievements of their countrymen and women, there is very widespread popular interest in this subject and its discoverers. 
While scholarly accounts published since The Discovery of Insulin now reflect its conclusions, popular understanding of the event has changed more gradually. It has been something like redirecting an ocean liner to alter the Banting and Best myth in favour of the more subtle, less alliterative notion of a collaboration involving Banting, Best, Collip, and Macleod. New encyclopaedia entries in The Canadian Encyclopaedia and The Dictionary of Canadian Biography have important popular influence. In the late 1980s the television mini-series, 'Glory Enough for All', gave much more attention to Macleod's contributions than had previous dramatisations, and it was shown around the world. While in the world of popularisation there are occasional muddles and confusions and reversions to Banting and Best mythology, in fact there is no longer neglect of Macleod, no longer resistance to a modern understanding of the discovery as a collaborative event. No one in 2013 would say that Macleod did not deserve his Nobel Prize.

At the University of Toronto in 1990 we erected our first major historical display to The Discovery of Insulin, and it reflected our new understanding of the collaboration, as did a new historical plaque. We also at that time named the large theatre in our Medical Sciences Building, on the site of the old building where the research took place, the JJR Macleod Auditorium. Anniversary celebrations now had a different focus. Whereas twenty-fifth and fiftieth anniversaries had all been about Banting and Best, by the time of seventy-fifth anniversary celebrations, which featured major symposia in Toronto and Copenhagen, the tendency was to honour all four discovers, though not without fierce resistance from members of the Best family.
In 2012 the University of Toronto and Canada celebrated the ninetieth anniversary of the discovery of insulin. At the heart of medical Toronto, in its great MaRS building, a new historical display was opened stressing the discovery as a collaborative event. At a celebratory dinner in Toronto all four of the discovers were honoured, beginning with my toast to JJR Macleod. One of the attendees at this dinner, the diabetologist Jesse Roth notes that the University of Toronto has finally formally acknowledged all four of the discoverers of insulin..$^{30}$ Also in 20I2, JJR Macleod was inducted into the Canadian Medical Hall of Fame, an institution taken seriously in our biomedical community. His nomination and induction were long overdue. Significantly, the nomination, which I made, was seconded by Charles Best's last graduate student, Dr Mladen Vranic.

Thanks to the efforts of Michael Williams and others, there is now increasing commemoration of Macleod's work and reputation in Aberdeen and in UK diabetes circles. Perhaps this article, based on the 20I3 Douglas Guthrie Lecture in Edinburgh, is another milestone in our appreciation of the life and work of a great and influential physiologist from Scotland. 


\section{REFERENCES}

I Banting FG, Best $\mathrm{CH}$, Collip JB et al. The effect produced on diabetes by extracts of pancreas. Trans Ass American Physicians 1922; XXXVII: 337-47.

2 Bliss M. J.JR. Macleod and the discovery of insulin. Q J Exp Physiol 1989; 74:87-96.

3 Williams MJ. JJR Macleod: the co-discoverer of insulin. Proc R Coll Physicians Edinb 1993; 23:1-125.

4 Bliss M. The discovery of insulin. Toronto: McClelland \& Stewart; London: Macmillan; 1982. http://dx.doi.org//0.7208/chicago/9780 226075631.001.0001

5 Bliss M. Banting: a biography. Toronto: McClelland \& Stewart; 1984.

6 Bliss M. The discovery of insulin. Toronto: McClelland \& Stewart; London: Macmillan; 1982. p. 196. http://dx.doi.org//0.7208/chicago/ 9780226075631.001.0001

7 Bliss M. Banting: a biography. Toronto: McClelland \& Stewart; 1984 PP. I20-7.

8 Bliss M. Banting: a biography. Toronto: McClelland \& Stewart; 1984 p. 179.

9 Banting FG. 1940 manuscript account of the story of insulin, typescript, pp. 33-4. Banting Papers, Fisher Library, University of Toronto.

10 G William Ross Papers, Fisher Library, University of Toronto. Bliss M. New light on Banting: the G William ("Billy") Ross Papers. Unpublished. Paper delivered to the Toronto Medical Historical Club, 24 February 2012.

II Notes in Box 7, Files 47, 48. G William Ross Papers, Fisher Library, University of Toronto.

I2 Li A. JB Collip and the development of medical research in Canada. Montreal and Kingston: McGill-Queen's University Press; 2003.

13 Bliss M. Rewriting medical history: Charles Best and the Banting and Best myth.J Hist Med Allied Sci 1993; 48:255-74. http://dx.doi. org/10.1093/jhmas/48.3.253

14 Feudtner C. Bittersweet: diabetes, insulin, and the transformation of illness. Chapel Hill and London: University of North Carolina Press; 2003.

15 Best HM. Margaret and Charley: the personal story of Dr Charles Best, the co-discoverer of insulin. Toronto, Oxford: Dundurn Press; 2003.

16 Lawrence J, Tattersall R, eds. Diabetes, insulin and the life of RD Lawrence. London: Royal Society of Medicine Press; 2012.
17 Letter, HH Dale to $\mathrm{CH}$ Best, 13 Sept 196I, Dale Papers, Royal Society of London. In: Bliss M. Rewriting medical history: Charles Best and the Banting and Best myth. J Hist Med Allied Sci 1993; 48:27I. http://dx.doi.org/I0.1093/jhmas/48.3.253

18 Notes, interview of Robin Lawrence by WR Feasby, 1965, Feasby Papers, Fisher Library, University of Toronto.

19 Notes of M Bliss interviews with JM Peterson (Edinburgh), lan Anderson (Aberdeen), Robert Garry (Comrie), October 1980. Bliss Insulin Papers, Fisher Library, University of Toronto.

20 Bliss M. Rewriting medical history: Charles Best and the Banting and Best myth. J Hist Med Allied Sci 1993; 48:267. http://dx.doi. org//0.1093/jhmas/48.3.253

21 Best HM. Margaret and Charley: the personal story of Dr Charles Best, the co-discoverer of insulin. Toronto, Oxford: Dundurn Press; 2003. Pp. 389-90.

22 Williams MJ. JJR Macleod: the co-discoverer of insulin. Proc $R$ Coll Physicians 1993; 23:105.

23 Email, I Macintyre to M Bliss, 6 March, 2013.

24 Bliss M. Writing history: a professor's life. Toronto: Dundurn Press; 20I I. Chapter 8.

25 Roberts F. Insulin. BMJ 1922; 2:I 193-4. http://dx.doi.org//0.1 I36/ bmj.2.3233.I193-a

26 Pratt $\mathrm{JH}$. A reappraisal of researches leading to the discovery of insulin. J Hist Med 1954; 9:28I-9.

27 Macleod JJR. History of the researches leading to the discovery of insulin. Bull Hist Med 1978; 52:295-312.

28 Tattersall R. Diabetes: the biography. Oxford: Oxford University Press; 2009.

29 Laron Z. Nicolae C Paulescu - scientist and politician. Paper presented at the Symposium on the History of Diabetes, Delphi, Greece, 7-9 September 2005. In: Bliss M. The discovery of insulin 25th anniversary ed.Toronto: University of Toronto Press; 2007.

30 Roth J, Qureshi S, Whitford I et al. Insulin's discovery: new insights on its ninetieth birthday. Diabetes Metab Res Rev 2012; 28:293-304. http://dx.doi.org/I0.1002/dmrr.2300 